\title{
The Role of Perceived Teaching Quality as Mediator Variable That Affects Student Satisfaction
}

\author{
Sopiah Sopiah $^{1 *}$, Ita P. Wilujeng ${ }^{1}$, A. Murdiono ${ }^{1}$, Etta Mamang Sangadji ${ }^{2}$ \\ ${ }^{1}$ Department of Management, Faculty of Economics, Universitas Negeri Malang, East Java, Indonesia \\ ${ }^{2}$ Department of Economics Education, Universitas Wira Negara Pasuruan, East Java, Indonesia \\ ${ }^{*}$ Corresponding author. Email: sopiah.fe@um.ac.id
}

\begin{abstract}
The purpose of this research is to explain the role of perceived teaching quality as a mediator variable that affects student satisfaction. Data was obtained from 180 lecturers and 600 students from 6 state and private universities in Indonesia. The sampling technique used was multistage sampling. The analysis technique used was statistical descriptive and path analysis. The research proves research: 1) There is a positive and significant direct effect of lecturer competency on perceived teaching quality; (2) There is a significant positive direct effect of lecturer competency on student satisfaction; (3) There is a significant positive direct effect of perceived teaching quality on student satisfaction (4) There is a significant positive indirect effect of lecturer competency on student satisfaction through perceived teaching quality; (5) There is a positive and significant direct effect of lecturer commitment to academic achievement on perceived teaching quality; (6) There is a significant positive direct effect of lecturer commitment to academic achievement on student satisfaction, (7) There is a significant positive direct effect of perceived teaching quality on student satisfaction; (8) There is a significant positive indirect effect of lecturer commitment to academic achievement on student satisfaction through perceived teaching quality.
\end{abstract}

\section{Keywords: Perceived teaching quality, Mediator variable, Student satisfaction, Path analysis}

\section{INTRODUCTION}

Research with the theme of lecturer commitment and lecturer competence, learning quality, and student satisfaction has attracted the interest of educators and researchers in the educational field, including; Kevin M. Elliott \& Dooyoung Shin (2010); Al-Mutairi, A. (2011); Minakshi Duggal, Pooja Mehta; Wamala, R. \& Seruwagi, G. (2013); Muzenda, A. (2013); Choi Sang Long, Zaiton Ibrahim \& Tan Owee Kowang (2014; Bonney, EA, Amoah, DP, Micah, SA, Ahiamenyo, C., \& Lemaire, MB (2015); Dian Anggraini Kusumajati, Justin Suhardi Ruman. (2017); Ng Chiaw Gee (2018).

This research is important and is still relevant because it has a number of updates, including (1) Most researchers do not examine lecturer competencies comprehensively (include: pedagogical competencies, social competencies, personality competencies and academic competencies), but only partial and noticing from one or two competencies; (2) The level of research scope. Most studies are narrow in scope. This research is wider in scope, including 180 lecturers and 600 students in 6 State and Private Universities in Indonesia; 3). Theoretically and empirically this study seeks to find clarity about the interrelationships between variables, because there are still many different or even contradictory opinions.
Student satisfaction is an important factor and serves as one of the spearheads for measuring college performance. Satisfied students will attract other prospective students to enter higher education. Satisfied students will talk to others and it is a free promotion for the college concerned. Therefore, student satisfaction becomes an urgent variable to continue to explore in order to obtain empirical evidence about the causes.

Based on the literature study, a number of variables were found that affected student satisfaction including: lecturer competency, lecturer commitment to academic achievement and perceived teaching quality.

The quality of operational learning can be interpreted as the intensity of systemic and synergic linkages between teachers, students, the learning climate, and learning media in producing optimal learning processes and outcomes in accordance with curricular demands (Haryati \& Rochman, 2012). According to Daryanto mentioned that the quality of learning is a level of achievement of the initial learning goals including the learning of art, in the achievement of these objectives in the form of increased knowledge, skills and the development of students' attitudes through the learning process in class (Prasetyo, 2013).

Lecturer competency is defined as a combination of talents and abilities possessed by lecturers. Includes pedagogic, personal, professional and social competencies. Lecturer commitment to academic achievement is defined as the willingness of lecturers to work hard and provide energy 
and time to support the academic achievement of the students.

Based on several researches, Lecturer Commitments to Academic Achievement, the positive and significant direct effect on Perceived Teaching Quality (Xiao, J. and Wilkins, S. (2015); Ahmad, J., Ather, MR, \& Hussain, M. (2014). Lecturer Competency has positive and direct effect on Perceived Teaching Quality (Choi Sang Long, Zaiton Ibrahim \& Tan Owee Komang (2014); Xiao, J. and Wilkins, S. (2015); Ng Chiaw Gee (2018). Lecturer competency has significant positive direct effect on student satisfaction (Lelya Hilda (2018); Suasan (2014); Deddy Prihadi (2018); Butt, BZ, \& Rehman, K. (2010). The Effect of Lecturer Competency on Student Satisfaction (Choi Sang Long, Zaiton Ibrahim \& Tan Owee Komang (2014); The effect of perceived Teaching Quality on Student Satisfaction (Akareem, HS \& Hossain, Sy.Sh (2016); Butt, BZ, \& Rehman, K. (2010). Indirect Effect of Lecturer Commitment to Academic Achievement on Student Satisfaction through Perceived Teaching Quality (Xiao, Jian. (2015), Al- Kuwaiti, A. Maruthamuthu, Th. (2014); Sookdeo, Suzette S., (2016). Indirect Effect of Lecturer Competency on Student Satisfaction through Perceived Teaching Quality (Jiewanto, A, Laurens, C \& Nelloh, L (2012); Hakim, A. (2015); Leyla Temizer, Ali Turkyilmazb (2012).

The purpose of this research is to explain the effect of lecturer competence and lecturer commitment on student satisfaction directly or indirectly through the quality of learning perceived by students.

\section{METHOD}

This research was designed using a quantitative approach. The type is explanatory research. The research variables consist of: exogenous variables, i.e. lecturer variable's commitment to academic achievement (X1) and competency lecturer (X2); moderating variable, which is perceived teaching quality $(\mathrm{Z})$, and endogenous variable, namely student satisfaction $(\mathrm{Y})$. Relationships that occur between the variables in this study can be described as follows:

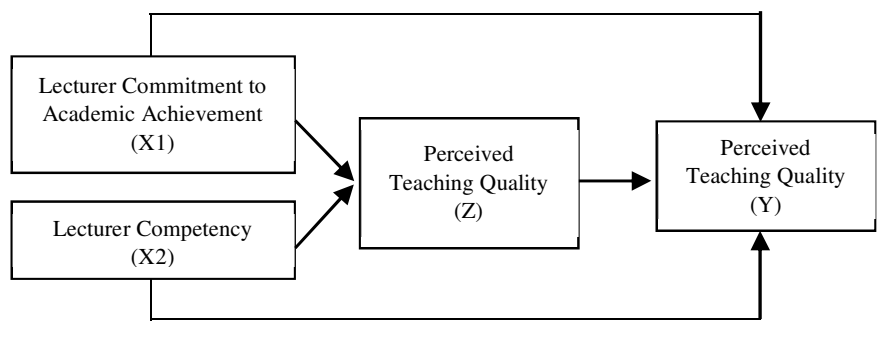

Picture 1. Research Framework
The population in this study were all lecturers and students of colleges/ universities in the city of Malang. The sampling technique is multistage. The first stage determines which colleges will be sampled, determined by 6 Colleges/ Universities. The second stage determines the sample size of each College/ University professionally. The number of samples is determined in a quota taking into account the number of students in each college/ university, set as many as 180 lecturers and 600 students in Indonesia. Before being used in research, research instruments (questionnaires) are tested first. A good instrument must meet two important requirements, namely valid and reliable.

Validity test is used to measure or test the items of each question in the questionnaire or questionnaire that will be filled in by the respondent. Sugiyono (2015) stated whether the instrument was valid or not by looking at the magnitude of the correlation coefficient $(r)>0.3$ declared valid. Test the validity of the variable items of this study using SPSS Statistics Version 16 for windows software. Here are the results of testing the instrument that has been carried out:

Table 1. Validity Test Variable: X1 (Lecturer's Commitment to Academic Achievement) Item-Total Statistics

\begin{tabular}{|l|r|r|r|r|}
\hline & $\begin{array}{c}\text { Scale } \\
\text { Mean if } \\
\text { Item } \\
\text { Deleted }\end{array}$ & $\begin{array}{c}\text { Scale } \\
\text { Variance if } \\
\text { Item } \\
\text { Deleted }\end{array}$ & $\begin{array}{c}\text { Corrected } \\
\text { Item- } \\
\text { Total } \\
\text { Correlation }\end{array}$ & $\begin{array}{c}\text { Cronbach' } \\
\text { Alpha if Item } \\
\text { Deleted }\end{array}$ \\
\hline $\mathrm{X} 1.1 \mathrm{a}$ & 30.03 & 17.068 & .725 & .941 \\
\hline $\mathrm{X} 1.1 \mathrm{~b}$ & 30.07 & 15.720 & .805 & .936 \\
\hline $\mathrm{X} 1.1 \mathrm{c}$ & 29.90 & 16.438 & .830 & .934 \\
\hline $\mathrm{X} 1.2 \mathrm{a}$ & 29.87 & 16.395 & .838 & .934 \\
\hline $\mathrm{X} 1.2 \mathrm{~b}$ & 30.33 & 15.747 & .843 & .933 \\
\hline $\mathrm{X} 1.3 \mathrm{a}$ & 30.20 & 15.752 & .870 & .931 \\
\hline $\mathrm{X} 1.3 \mathrm{~b}$ & 30.30 & 16.562 & .658 & .947 \\
\hline $\mathrm{X} 1.3 \mathrm{c}$ & 29.87 & 16.395 & .838 & .934 \\
\hline
\end{tabular}


Variable: X2 (Lecturer Competency)

Item-Total Statistics

\begin{tabular}{|l|c|c|c|c|}
\hline & $\begin{array}{c}\text { Scale Mean } \\
\text { if Item } \\
\text { Deleted }\end{array}$ & $\begin{array}{c}\text { Scale } \\
\text { Variance } \\
\text { if Item } \\
\text { Deleted }\end{array}$ & $\begin{array}{c}\text { Corrected } \\
\text { Item- } \\
\text { Total } \\
\text { Correlation }\end{array}$ & $\begin{array}{c}\text { Cronbach's } \\
\text { Alpha if } \\
\text { Item } \\
\text { Deleted }\end{array}$ \\
\hline X2.1a & 71.23 & 95.220 & .800 & .965 \\
\hline X2.1b & 71.37 & 94.654 & .795 & .965 \\
\hline X2.1c & 71.57 & 93.289 & .864 & .964 \\
\hline X2.1d & 71.67 & 95.540 & .647 & .967 \\
\hline X2.1e & 71.70 & 92.286 & .761 & .966 \\
\hline X2.2a & 71.40 & 95.352 & .748 & .966 \\
\hline X2.2b & 71.50 & 96.879 & .561 & .969 \\
\hline X2.2c & 71.60 & 92.041 & .918 & .964 \\
\hline X2.2d & 71.57 & 93.771 & .769 & .966 \\
\hline X2.3a & 71.67 & 93.471 & .799 & .965 \\
\hline X2.3b & 71.77 & 91.909 & .831 & .965 \\
\hline X2.3c & 71.50 & 94.466 & .797 & .965 \\
\hline X2.3d & 71.60 & 96.593 & .684 & .967 \\
\hline X2.3e & 71.63 & 94.999 & .851 & .965 \\
\hline X2.4a & 71.43 & 93.426 & .790 & .965 \\
\hline X2.4b & 71.27 & 95.168 & .805 & .965 \\
\hline X2.4c & 71.23 & 95.220 & .800 & .965 \\
\hline X2.4d & 71.77 & 91.909 & .831 & .965 \\
\hline & & & & 965 \\
\hline
\end{tabular}

Variable: Z (Perceived Teaching Quality)

Item-Total Statistics

\begin{tabular}{|l|r|r|r|r|}
\hline & $\begin{array}{c}\text { Scale } \\
\text { Mean if } \\
\text { Item } \\
\text { Deleted }\end{array}$ & $\begin{array}{c}\text { Scale } \\
\text { Variance if } \\
\text { Item } \\
\text { Deleted }\end{array}$ & $\begin{array}{c}\text { Corrected } \\
\text { Item- } \\
\text { Total } \\
\text { Correlation }\end{array}$ & $\begin{array}{c}\text { Cronbach's } \\
\text { Alpha if Item } \\
\text { Deleted }\end{array}$ \\
\hline $\mathrm{Z.1a}$ & 37.43 & 27.426 & .761 & .945 \\
\hline $\mathrm{Z} .1 \mathrm{~b}$ & 37.63 & 26.171 & .915 & .938 \\
\hline $\mathrm{Z} .1 \mathrm{c}$ & 37.73 & 27.375 & .682 & .949 \\
\hline $\mathrm{Z} .1 \mathrm{~d}$ & 37.77 & 25.564 & .804 & .944 \\
\hline $\mathrm{Z} .2 \mathrm{a}$ & 37.30 & 27.734 & .764 & .945 \\
\hline $\mathrm{Z} .2 \mathrm{~b}$ & 37.77 & 26.254 & .873 & .940 \\
\hline $\mathrm{Z} .2 \mathrm{c}$ & 37.63 & 26.171 & .915 & .938 \\
\hline $\mathrm{Z} .2 \mathrm{~d}$ & 37.57 & 27.357 & .758 & .951 \\
\hline $\mathrm{Z} .3 \mathrm{a}$ & 37.67 & 28.713 & .607 & .944 \\
\hline $\mathrm{Z} .3 \mathrm{~b}$ & 37.70 & 27.666 & .808 & \\
\hline
\end{tabular}

Variable: Y (Student Satisfaction)

Item-Total Statistics

\begin{tabular}{|l|r|r|r|r|}
\hline & $\begin{array}{c}\text { Scale } \\
\text { Mean if } \\
\text { Item } \\
\text { Deleted }\end{array}$ & $\begin{array}{c}\text { Scale } \\
\text { Variance if } \\
\text { Item } \\
\text { Deleted }\end{array}$ & $\begin{array}{c}\text { Corrected } \\
\text { Item- } \\
\text { Total } \\
\text { Correlation }\end{array}$ & $\begin{array}{c}\text { Cronbach's } \\
\text { Alpha if Item } \\
\text { Deleted }\end{array}$ \\
\hline Y.1a & 62.93 & 74.754 & .790 & .966 \\
\hline Y.1b & 63.03 & 76.447 & .695 & .968 \\
\hline Y.1c & 63.07 & 74.961 & .871 & .965 \\
\hline
\end{tabular}

\begin{tabular}{|c|l|l|l|l|}
\hline Y.1d & 62.83 & 75.385 & .755 & .967 \\
\hline Y.2a & 62.77 & 77.564 & .666 & .968 \\
\hline Y.2b & 62.93 & 77.030 & .542 & .970 \\
\hline Y.2c & 63.03 & 73.137 & .866 & .965 \\
\hline Y.2d & 63.07 & 72.064 & .920 & .964 \\
\hline Y.3a & 63.00 & 74.621 & .844 & .966 \\
\hline Y.3b & 63.10 & 73.059 & .861 & .965 \\
\hline Y.3c & 63.20 & 71.752 & .882 & .965 \\
\hline Y.3d & 62.87 & 73.568 & .805 & .966 \\
\hline Y.4a & 62.70 & 75.666 & .770 & .967 \\
\hline Y.4b & 62.67 & 75.816 & .755 & .967 \\
\hline Y.4c & 63.10 & 73.059 & .861 & .965 \\
\hline Y.4d & 63.20 & 71.752 & .882 & .965 \\
\hline
\end{tabular}

All items of 4 variables were declared valid because the value of $r$ hit $>0.3$ (Sugiyono (2015).

After the validity test, the reliability test was carried out, by looking at the Cronbach alpha value. The four variables are said to be reliable because they have an alpha coefficient a $>0.6$. Here are the results of the reliability test.:

Table 2. Reliability Test Results Table

\begin{tabular}{|c|c|c|c|c|}
\hline No & Variable & $\begin{array}{c}\text { Alpha } \\
\text { Coefficient }\end{array}$ & $\begin{array}{c}\text { Alpha } \\
\text { Coefficient } \\
\text { Standard }\end{array}$ & Result \\
\hline 1. & $\begin{array}{l}\text { Lecturer commitment } \\
\text { to academic } \\
\text { achievement (X1) }\end{array}$ & 944 & 0,6 & Reliable \\
\hline 2. & $\begin{array}{l}\text { Lecturer competency } \\
\text { (X2) }\end{array}$ & .968 & 0,6 & Reliable \\
\hline 3. & $\begin{array}{l}\text { Perceived Teaching } \\
\text { Quality }(Z)\end{array}$ & .949 & 0,6 & Reliable \\
\hline 4. & $\begin{array}{l}\text { Student } \\
\text { Satisfaction(Y) }\end{array}$ & .968 & 0,6 & Reliable \\
\hline
\end{tabular}

The technique of data collection is done by spreading closed questionnaires with 5 alternative choices: strongly agree, agree, neutral, disagree and strongly disagree. After the data is collected, data analysis is performed using descriptive statistics and path analysis.

\section{RESULT AND DISCUSSION}

1. Characteristics of Respondents

Respondents in this study consisted of 180 lecturers and 600 students from 6 state and private universities in Indonesia. Descriptions of respondents based on age, gender, and faculty can be seen in the following table: 
Table 3. Description of Respondents by Age

\begin{tabular}{|c|c|c|c|}
\hline No & Age & Frequency & Percentage (\%) \\
\hline 1 & $<30$ year & 110 & 0,18 \\
\hline 2 & $30.1-40$ years & 130 & 0,22 \\
\hline 3 & $40.1>50$ year & 206 & 0,34 \\
\hline 4 & $>51$ & 154 & 0,26 \\
\hline & Total & $\mathbf{6 0 0}$ & $\mathbf{1 0 0}$ \\
\hline
\end{tabular}

Table 4. Description of Respondents by Gender

\begin{tabular}{|c|l|c|c|}
\hline No & Gender & Frequency & Percentage (\%) \\
\hline 1 & Female & 292 & 0,48 \\
\hline 2 & Male & 308 & 0,52 \\
\hline & Total & $\mathbf{6 0 0}$ & $\mathbf{1 0 0}$ \\
\hline
\end{tabular}

Table 5. Descriptions of Respondents by Faculty

\begin{tabular}{|c|c|c|c|}
\hline No & Faculty & Frequency & Percentage (\%) \\
\hline 1 & Economy & 125 & 0,20 \\
\hline 2 & Education & 98 & 0,16 \\
\hline 3 & Language & 92 & 0,15 \\
\hline 4 & Techniques & 105 & 0,18 \\
\hline 5 & MIPA & 105 & 0,17 \\
\hline 6 & Others & 45 & 0,07 \\
\hline & Total & $\mathbf{6 0 0}$ & $\mathbf{1 0 0}$ \\
\hline
\end{tabular}

2. Descriptive Statistics Analysis Results

Lecturer commitment to academic achievement in this study is measured by 3 indicators, namely: 1) Lecturers Commitment to improve student competence, 2) Lecturers Commitment to increase student motivation and 3)
Lecturers Commitment to create a conducive learning environment. The three indicators are explained into 8 statement items. Here are the results:

Table 6. Results of Descriptive Analysis of Lecturer's Commitment to Academic Achievement (X1)

\begin{tabular}{|c|c|c|c|c|c|c|c|c|c|c|c|}
\hline \multirow{3}{*}{ Item No } & \multicolumn{10}{|c|}{ Respondents' Answers } & \multirow{3}{*}{ Mean } \\
\hline & \multicolumn{2}{|c|}{5} & \multicolumn{2}{|c|}{4} & \multicolumn{2}{|c|}{3} & \multicolumn{2}{|c|}{2} & \multicolumn{2}{|c|}{1} & \\
\hline & $\mathbf{F}$ & $\%$ & $\mathbf{F}$ & $\%$ & $\mathbf{F}$ & $\%$ & $\mathbf{F}$ & $\%$ & $\mathbf{F}$ & $\%$ & \\
\hline $\mathrm{X} 1.1 \mathrm{a}$ & 37 & 3,1 & 33 & 2,8 & 130 & 11,0 & 400 & 66,7 & 0 & 0 & 2,51 \\
\hline $\mathrm{X} 1.1 \mathrm{~b}$ & 264 & 22,4 & 298 & 25,3 & 38 & 3,2 & 0 & 0 & 0 & 0 & 4,38 \\
\hline $\mathrm{X} 1.1 \mathrm{c}$ & 262 & 22,3 & 312 & 26,5 & 26 & 2,2 & 0 & 0 & 0 & 0 & 4,39 \\
\hline $\mathrm{X} 1.2 \mathrm{a}$ & 19 & 1,6 & 9 & 0,8 & 183 & 15,5 & 389 & 33,1 & 0 & 0 & 2,43 \\
\hline $\mathrm{X} 1.2 \mathrm{~b}$ & 286 & 24,3 & 287 & 24,4 & 24 & 2,0 & 3 & 0,3 & 0 & 0 & 4,43 \\
\hline $\mathrm{X} 1.3 \mathrm{a}$ & 29 & 2,5 & 41 & 3,5 & 151 & 12,8 & 379 & 32,2 & 0 & 0 & 2,53 \\
\hline $\mathrm{X} 1.3 \mathrm{~b}$ & 267 & 22,7 & 320 & 27,2 & 11 & 0,9 & 2 & 0,2 & 0 & 0 & 4,42 \\
\hline $\mathrm{X} 1.3 \mathrm{c}$ & 288 & 24,5 & 288 & 224,5 & 22 & 1,9 & 2 & 0,2 & 0 & 0 & 4,44 \\
\hline \multicolumn{11}{|c|}{ Grand Mean } & 3,69 \\
\hline
\end{tabular}

Table 6 explains that the grand mean of the lecturer commitment variable to academic achievement (X1) is 3.69 including the high category. The lowest score on the 3. Lecturer Competency (X2)

Lecturer Competency (X2) variable is measured by 4 competencies (dimensions), namely pedagogic indicator of lecturer commitment to increase student motivation in the statement gives rewards to students who succeeded in the academic field.

competence, personal competence, professional competence and social competence. The four competencies are explained into 18 statement items. Table 7 explains that 
the grand mean of the Lecturer Competency variable is 4.03, included in the high category. This means that students perceive the competence of lecturers as high. The lowest value lies in the indicator of personal competence, namely the lecturer cannot yet be a role model for students in thinking attitude and behavior.

Table 7. Results of Descriptive Analysis of Lecturer Competency (X2)

\begin{tabular}{|c|c|c|c|c|c|c|c|c|c|c|c|}
\hline \multirow[t]{3}{*}{ Item No } & \multicolumn{10}{|c|}{ Respondents' Answers } & \multirow[t]{3}{*}{ Mean } \\
\hline & \multicolumn{2}{|c|}{5} & \multicolumn{2}{|c|}{4} & \multicolumn{2}{|c|}{3} & \multicolumn{2}{|c|}{2} & \multicolumn{2}{|c|}{$\mathbf{1}$} & \\
\hline & $\mathbf{F}$ & $\%$ & $\mathbf{F}$ & $\%$ & $\mathbf{F}$ & $\%$ & $\mathbf{F}$ & $\%$ & $\mathbf{F}$ & $\%$ & \\
\hline $\mathrm{X} 2.1 \mathrm{a}$ & 262 & 43,7 & 312 & 52,0 & 26 & 4,3 & 0 & 0 & 0 & 0 & 4,39 \\
\hline $\mathrm{X} 2.1 \mathrm{~b}$ & 182 & 30,3 & 366 & 61,0 & 52 & 8,7 & 0 & 0 & 0 & 0 & 4,22 \\
\hline $\mathrm{X} 2.1 \mathrm{c}$ & 156 & 26,0 & 375 & 62,5 & 66 & 11,0 & 3 & 0,5 & 0 & 0 & 4,14 \\
\hline $\mathrm{X} 2.1 \mathrm{~d}$ & 286 & 47,7 & 288 & 48,0 & 24 & 4,0 & 2 & 0,3 & 0 & 0 & 4,43 \\
\hline $\mathrm{X} 2.1 \mathrm{e}$ & 100 & 16,7 & 258 & 43,0 & 197 & 32,8 & 41 & 6,8 & 4 & 0,7 & 3,68 \\
\hline $\mathrm{X} 2.2 \mathrm{a}$ & 178 & 29,7 & 356 & 59,3 & 66 & 11,0 & 0 & 0 & 0 & 0 & 4,19 \\
\hline $\mathrm{X} 2.2 \mathrm{~b}$ & 9 & 1,5 & 21 & 3,5 & 237 & 39,5 & 333 & 55,5 & 0 & 0 & 2,51 \\
\hline $\mathrm{X} 2.2 \mathrm{c}$ & 199 & 33,2 & 362 & 60,3 & 39 & 6,5 & 0 & 0 & 0 & 0 & 4,27 \\
\hline $\mathrm{X} 2.2 \mathrm{~d}$ & 193 & 32,2 & 332 & 55,3 & 71 & 11,8 & 2 & 0,3 & 2 & 0,3 & 4,19 \\
\hline $\mathrm{X} 2.3 \mathrm{a}$ & 5 & 0,8 & 25 & 4,2 & 251 & 41,8 & 318 & 53,0 & 1 & 0,2 & 2,52 \\
\hline $\mathrm{X} 2.3 \mathrm{~b}$ & 267 & 44,5 & 321 & 53,5 & 10 & 1,7 & 2 & 0,3 & 0 & 0 & 4,42 \\
\hline $\mathrm{X} 2.3 \mathrm{c}$ & 192 & 32,0 & 332 & 55,3 & 72 & 12,0 & 2 & 0,3 & 2 & 0,3 & 4,18 \\
\hline $\mathrm{X} 2.3 \mathrm{~d}$ & 162 & 27,0 & 365 & 60,8 & 70 & 11,7 & 2 & 0,3 & 1 & 0,2 & 4,14 \\
\hline $\mathrm{X} 2.3 \mathrm{e}$ & 182 & 30,3 & 366 & 61,0 & 52 & 8,7 & 0 & 0 & 0 & 0 & 4,22 \\
\hline $\mathrm{X} 2.4 \mathrm{a}$ & 262 & 43,7 & 300 & 50,0 & 38 & 6,3 & 0 & 0 & 0 & 0 & 4,37 \\
\hline $\mathrm{X} 2.4 \mathrm{~b}$ & 286 & 47,7 & 288 & 48,0 & 24 & 4,0 & 2 & 0,3 & 0 & 0 & 4,43 \\
\hline $\mathrm{X} 2.4 \mathrm{c}$ & 148 & 24,7 & 376 & 62,7 & 72 & 12,0 & 4 & 0,7 & 0 & 0 & 4,11 \\
\hline $\mathrm{X} 2.4 \mathrm{~d}$ & 175 & 29,2 & 362 & 60,3 & 61 & 10,2 & 2 & 0,3 & 0 & 0 & 4,18 \\
\hline \multicolumn{11}{|c|}{ Grand Mean } & 4,03 \\
\hline
\end{tabular}

4. Perceived Teaching Quality (Z)

Perceived Teaching Quality is measured by 3 indicators,

namely: learning planning, learning implementation and

learning assessment. Here are the results of student answers:

Table 8. Results of Descriptive Analysis of Perceived Teaching Quality (Z)

\begin{tabular}{|c|c|c|c|c|c|c|c|c|c|c|c|}
\hline \multirow[t]{3}{*}{ Item No } & \multicolumn{10}{|c|}{ Respondents' Answers } & \multirow[t]{3}{*}{ Mean } \\
\hline & \multicolumn{2}{|c|}{5} & \multicolumn{2}{|c|}{4} & \multicolumn{2}{|c|}{3} & \multicolumn{2}{|c|}{2} & \multicolumn{2}{|c|}{1} & \\
\hline & $\mathbf{F}$ & $\%$ & $\mathbf{F}$ & $\%$ & $\mathbf{F}$ & $\%$ & $\mathbf{F}$ & $\%$ & $\mathbf{F}$ & $\%$ & \\
\hline Z.1a & 262 & 43,7 & 312 & 52,0 & 26 & 4,3 & 0 & 0 & 0 & 0 & 4,39 \\
\hline Z.1b & 262 & 43,7 & 300 & 50,0 & 38 & 6,3 & 0 & 0 & 0 & 0 & 4,37 \\
\hline Z.1c & 175 & 29,2 & 336 & 56,0 & 85 & 14,2 & 4 & 0,7 & 0 & 0 & 4,14 \\
\hline Z.1d & 286 & 47,7 & 288 & 48,0 & 24 & 4,0 & 2 & 0,3 & 0 & 0 & 4,43 \\
\hline Z.2a & 306 & 51,0 & 284 & 47,3 & 8 & 1,3 & 2 & 0,3 & 0 & 0 & 4,49 \\
\hline$\overline{Z .2 b}$ & 279 & 46,5 & 286 & 47,7 & 35 & 5,8 & 0 & 0 & 0 & 0 & 4,41 \\
\hline $\mathrm{Z} .2 \mathrm{c}$ & 276 & 46,0 & 298 & 49,7 & 26 & 4,3 & 0 & 0 & 0 & 0 & 4,42 \\
\hline$\overline{Z .2 d}$ & 314 & 52,3 & 262 & 43,7 & 24 & 4,0 & 0 & 0 & 0 & 0 & 4,48 \\
\hline Z.3a & 262 & 43,7 & 300 & 50,0 & 38 & 6,3 & 0 & 0 & 0 & 0 & 4,37 \\
\hline Z.3b & 306 & 51,0 & 269 & 44,8 & 24 & 4,0 & 1 & 0,2 & 0 & 0 & 4,47 \\
\hline & & & & Gra & Me & & & & & & $\mathbf{4 , 3 9}$ \\
\hline
\end{tabular}


Grand Mean of Perceived Teaching Quality variable of 4.39 is categorized high. This means that students perceive that the quality of learning is good. Nevertheless, there are still values below the average namely the ability of lecturers in designing instructional media.
5. Student Satisfaction Variables (Y)

Student satisfaction is measured by 4 indicators, namely: direct evidence, guarantees, responsiveness, and reliability. The four indicators are explained into 16 statement items. The following are the results of student answers.

Table 9. Results of Descriptive Analysis of Student Satisfaction (Y)

\begin{tabular}{|c|c|c|c|c|c|c|c|c|c|c|c|}
\hline \multirow{3}{*}{$\begin{array}{l}\text { Item } \\
\text { No }\end{array}$} & \multicolumn{10}{|c|}{ Respondents' Answers } & \multirow[t]{3}{*}{ Mean } \\
\hline & \multicolumn{2}{|c|}{5} & \multicolumn{2}{|c|}{4} & \multicolumn{2}{|c|}{3} & \multicolumn{2}{|c|}{2} & \multicolumn{2}{|c|}{1} & \\
\hline & $\mathbf{F}$ & $\%$ & $\mathbf{F}$ & $\%$ & $\mathbf{F}$ & $\%$ & $\mathbf{F}$ & $\%$ & $\mathbf{F}$ & $\%$ & \\
\hline Y.1a & 3 & 0,5 & 11 & 1,8 & 267 & 44,5 & 316 & 52,7 & 3 & 0,5 & 2,49 \\
\hline Y. 1b & 148 & 24,7 & 372 & 62,0 & 74 & 12,3 & 6 & 1,0 & 0 & 0 & 4,10 \\
\hline Y.1c & 1 & 0,2 & 32 & 5,3 & 297 & 49,5 & 268 & 44,7 & 2 & 0,3 & 2,60 \\
\hline Y.1d & 8 & 1,3 & 21 & 3,5 & 245 & 40,8 & 326 & 54,3 & 0 & 0 & 2,52 \\
\hline Y.2a & 286 & 47,7 & 288 & 48,0 & 24 & 4,0 & 2 & 0,3 & 0 & 0 & 4,43 \\
\hline Y.2b & 1 & 0,2 & 4 & 0,7 & 270 & 45,0 & 325 & 54,2 & 0 & 0 & 2,47 \\
\hline Y.2c & 158 & 26,3 & 346 & 57,7 & 92 & 15,3 & 4 & 0,7 & 0 & 0 & 4,10 \\
\hline Y.2d & 286 & 47,7 & 288 & 48,0 & 24 & 4,0 & 2 & 0,3 & 0 & 0 & 4,43 \\
\hline Y.3a & 132 & 22,0 & 384 & 64,0 & 74 & 12,3 & 10 & 1,7 & 0 & 0 & 4,06 \\
\hline Y.3b & 5 & 0,8 & 20 & 3,3 & 246 & 41,0 & 326 & 54,3 & 3 & 0,5 & 2,50 \\
\hline Y.3c & 0 & 0 & 0 & 0 & 231 & 38,5 & 368 & 61,3 & 1 & 0,2 & 2,38 \\
\hline Y.3d & 182 & 30,3 & 366 & 61,0 & 52 & 8,7 & 0 & 0 & 0 & 0 & 4,22 \\
\hline Y.4a & 307 & 51,2 & 217 & 45,2 & 21 & 3,5 & 1 & 0,2 & 0 & 0 & 4,47 \\
\hline Y.4b & 1 & 0,2 & 3 & 0,5 & 268 & 44,7 & 328 & 54,7 & 0 & 0 & 2,46 \\
\hline Y.4c & 181 & 30,2 & 350 & 58,3 & 64 & 10,7 & 5 & 0,8 & 0 & 0 & 4,18 \\
\hline Y.4d & 134 & 22,3 & 406 & 67,7 & 56 & 9,3 & 2 & 0,3 & 2 & 0,3 & 4,11 \\
\hline \multicolumn{11}{|c|}{ Grand Mean } & 3,47 \\
\hline
\end{tabular}

The grand mean value for the student satisfaction variable is 3.47 including the high or satisfied category. Although students are satisfied with direct/ physical evidence, guarantees, responsiveness, and reliability, students still assess students' aspirations have not been heard and followed up by university leaders and staff to the fullest.
6. Path Analysis Results

1. The Direct Effect of Lecturer Commitment to Student Academic Achievement (X1) and Lecturer Competency (X2) on Perceived Teaching Quality (Z)

Based on the regression test that has been done, the recapitulation of the path coefficient results of the influence of the variables $\mathrm{X} 1$ and $\mathrm{X} 2$ to $\mathrm{Z}$ can be seen in table 1.1 as follows:

Table 10. Regression Results of Structure Equation 1 from variables X1, X2, and Z

\begin{tabular}{|c|c|c|c|c|}
\hline Model & $\mathrm{R}$ & R Square & Adjusted R Square & Std. Error of the estimate \\
\hline 1 & $.623^{\mathrm{a}}$ & .388 & .386 & .344 \\
\hline
\end{tabular}

a. Predictors: (Constant), Lecturer Competency, Lecturer Commitment to Student Academic Achievement

Coefficients $^{\mathrm{a}}$

\begin{tabular}{|c|c|c|c|c|c|c|}
\hline & \multirow[t]{2}{*}{ Model } & \multicolumn{2}{|c|}{ Unstandardized Coefficients } & \multirow{2}{*}{$\begin{array}{c}\begin{array}{r}\text { Standardized } \\
\text { Coefficients }\end{array} \\
\text { Beta } \\
\end{array}$} & \multirow[t]{2}{*}{$\mathrm{t}$} & \multirow[t]{2}{*}{ Sig. } \\
\hline & & B & Std. Error & & & \\
\hline \multirow[t]{3}{*}{1} & (Constant) & .984 & .178 & & 5.524 & .000 \\
\hline & $\begin{array}{l}\text { Lecturer Commitment to } \\
\text { Student Academic } \\
\text { Achievement }\end{array}$ & .572 & .052 & .434 & 11.072 & .000 \\
\hline & Lecturer Competency & .323 & .048 & .261 & 6.664 & .000 \\
\hline
\end{tabular}

a. Dependent Variable: Teaching Quality

Based on the analysis results in the above table, the regression equation can be formulated as follows:

Structure Equation 1:
$\mathrm{Z}=0.434 \mathrm{X} 1+0.261 \mathrm{X} 2+0.782$

a. Based on Table 10, the results show that the Lecturer Commitment to Academic Achievement has a positive and significant direct effect on Perceived Teaching 
Quality of 0.434 ; with sig t $0.000<0.05$; (Hypothesis 1 is accepted). This means that if the Perceived Teaching Quality rises $1 \%$, the lecturer commitment to academic achievement will increase by $43.4 \%$. The results of this study support the results of research by Elliott, K.M., \& Shin, D. (2010); Xiao, J. and Wilkins, S. (2015); Paechter, M., Maier, B., \& Macher, D. (2010); Rienties, B., Heliot, YF, \& Jindal-Snape, D. (2013; Sojkin, B., Bartkowiak, P., \& Skuza, A. (2012); Tyler, TJ, Hilton III, J., Plummer, K., \& Barrett, D. (2014).

b. $\quad$ Based on Table 10, the results show that Lecturer Competency has a direct positive and significant effect on Perceived Teaching Quality $(\mathrm{Z})$ of 0.261 , with sig t $0.00<$ 0.05 (Hypothesis 2 is accepted). This means that if perceived teaching quality rises by $1 \%$, Lecturer Competency will increase by $26.1 \%$. The results of this study support the results of Tomo Judin's research. (2018), he researched students in Pontianak Indonesia. The results of his study concluded that the commitment of lecturers to academic achievement of students affect student satisfaction. This research strengthens the research of Xiao, Jian. (2015) examined at one Chinese University, with a sample consisted of 24 lecturers and 456 students in China. The purpose of the study was to examine the effect of lecturer commitment on student perceptions of teaching quality and student satisfaction. One of the results of his research concluded that the lecturers' commitment to student academic achievement had a positive and significant effect on student satisfaction.

2. The Direct Effect of Lecturer Commitment to Student Academic Achievement (X1) and Lecturer Competency (X2) on Student Satisfaction (Y) Through Perceived Teaching Quality (Z)

Based on the regression test that has been done, the path coefficient results of the variables $\mathrm{X} 1, \mathrm{X} 2$, and $\mathrm{Z}$ on $\mathrm{Y}$ can be seen in table 11 as follows:

Table 11. Regression Results of Structure Equation 2 from variables X1, X2, Z, and Y Model Summary

\begin{tabular}{|c|c|c|c|c|}
\hline \multirow{2}{*}{ Model } & R & R Square & Adjusted R Square & $\begin{array}{c}\text { Std. Error of the } \\
\text { estimate }\end{array}$ \\
\hline 1 & $.694^{\mathrm{a}}$ & .481 & .478 & .175 \\
\hline
\end{tabular}

a. Predictors: (Constant), Teaching Quality, Lecturer Competency, Lecturer Commitment to Student Academic Achievement

Coefficients*

a. Dependent Variable: Student Satisfaction

\begin{tabular}{|c|c|c|c|c|c|}
\hline \multirow[t]{2}{*}{ Model } & \multicolumn{2}{|c|}{ Unstandardized Coefficients } & \multirow{2}{*}{$\begin{array}{l}\text { Standardized } \\
\text { Coefficients } \\
\text { Beta }\end{array}$} & \multirow[t]{2}{*}{$\mathrm{t}$} & \multirow[t]{2}{*}{ Sig. } \\
\hline & B & Std. Error & & & \\
\hline $1 \quad$ (Constant) & 1.420 & .093 & & 15.275 & .000 \\
\hline $\begin{array}{l}\text { Lecturer Commitment } \\
\text { Student Academic } \\
\text { Achievement }\end{array}$ & .087 & .029 & .119 & 3.010 & .003 \\
\hline Lecturer Competency & .143 & .026 & .209 & 5.592 & .000 \\
\hline Teaching Quality & .263 & .021 & .475 & 12.604 & .000 \\
\hline
\end{tabular}

c. a. Dependent Variable: Student Satisfaction

\section{Structure Equation 2:}

$\mathrm{Y}=0.119 \mathrm{X} 1+0.209 \mathrm{X} 2+0.475 \mathrm{Z}+0.720$

a. The Effect of Lecturer Commitment to student academic achievement on Student satisfaction

Based on Table 11, the results are obtained that the Lecturer Commitment to student academic achievement has a significant positive effect on Student satisfaction of 0.119 and sig $\mathrm{t}=0.003<0.005$. Thus Hypothesis 3 is accepted. The results of this study support the results of ones conducted by Douglas, J.A., McClelland, Robert James. Douglas, A. (2015) concluded in his study that lecturer' commitment to student academic achievement has an effect on student satisfaction. The results of this study reinforce the research of Michael D. Clemes (2001). He conducted a cross-sectional study of 350 undergraduate students at two business schools of north western universities in England. He examined what factors caused students to be satisfied or dissatisfied with the services provided by universities in the UK. Satisfaction / dissatisfaction in the field of teaching and learning and learning environment factors, and support services. The quality of learning, campus facilities and the environment, and the educational process have a significant impact on student perceptions of service quality. Factors of student perceptions of higher education services have an effect on student satisfaction and loyalty to the institution. b. The Effect of Lecturer Competency on Student Satisfaction 
Based on Table 11, the results show that Lecturer Competency has a significant positive effect on Student Satisfaction of 0.209 and sit $=0.000<0.005$, thus Hypothesis 4 is accepted. The results of this research support the results of the one by $\mathrm{Ng}$ Chiaw Gee. (2018), he did a research to find out the effect of lecturer competence on student satisfaction. Using quantitative approaches and correlation analysis tools, and multiple regression. He collected 327 data from a total population of 2,226 . Of the 327 data, 80 data were collected from the Degree program, 214 data were collected from the Diploma program, 10 data were collected from the Certificate program, 23 data were collected from the Foundation program. He examined 10 indicators to measure lecturer competence: Knowledge. Course Objective, Lecture Note, Clarity of Presentation, Attendance, Class Activity, Assignment, Examination, Interpersonal Skills, and feedback are related to student satisfaction. His research findings conclude that lecturer competency has a positive and significant effect on student satisfaction. Akinleke W. Olaitan (2018) studied the last sixty students of the National Diploma (ND II) of the Federal Polytechnic, Ilaro, Ogun State, Nigeria. The results of his study concluded that lecturer competence affects student performance. The results of this research also strengthen the research results of Choi Sang Long, Zaiton Ibrahim \& Tan Owee Komang (2014) conducted a study of 260 students in private universities in Malaysia. They research about the competence of lecturers associated with student satisfaction. There are 14 lecturer competencies studied, including: competency, knowledge of subject, clarity of presentation, interaction with students, learning creativity, clarifying learning outcomes, class activity, lecture notes that affect student satisfaction. Of the 14 lecturer competencies, 1 competency which contributes the most significant effect on student satisfaction is lecturer knowledge of subject. Subsequent researchers Xiao, J. and Wilkins, S. (2015), conducted a study of 24 lecturers and 456 students at one university in China. The research findings concluded that the commitment of lecturers to perceived teaching quality affects student satisfaction. Lecturer commitment to all aspects of student social influence student satisfaction. Lecturer commitment has an effect on perceived teaching quality.

c. The Effect of Perceived Teaching Quality on Student Satisfaction

Based on Table 11, the results show that Perceived Teaching Quality has a significant positive effect on Student Satisfaction of 0.475 and $\operatorname{sig} t=0,000<0.005$. Thus hypothesis 5 is accepted. The results of this study support the results of the research of Butt, B.Z., \& Rehman, K. (2010) who examined the factors that shape student satisfaction in tertiary institutions which ultimately are student loyalty to the institution. The results of his research concluded that the factors forming student satisfaction are the image of the institution, student expectations, the quality perceived by students, including the quality of learning perceived by students and other factors are the values perceived by students. Temizer, L. and Turkyilmazb, A. (2012) conducted a research to measure student satisfaction from various aspects, such as university image, expectations, perceived quality, perceived value, and loyalty. The results of his research concluded that the factor was tested as a factor forming student satisfaction. The results of this study are in line with the results of research by Akareem H.S. \& Hossain Sy. Sh (2016) they examined university students in Bangladesh. The findings show students' perceptions about the quality of education, of course, including the quality of learning in higher education have an impact on student satisfaction in college in Bangladesh.

3. Indirect Effects of Lecturer Commitment to Student Academic Achievement (X1) on Student Satisfaction (Y) through Perceived Teaching Quality (Z) Based on these calculations it can be explained that the indirect effect of the Lecturer Commitment to Student Academic Achievement (X1) on Student Satisfaction (Y) through Teaching Quality $(\mathrm{Z})$ is $20.6 \%$. In addition, the results of the sub-structural calculation of Lecturer Commitment to Student Academic Achievement (X1) have an effect on Teaching Quality (Z) with a beta value of 0.434 and a significant level of $0,000<0.05$ then Teaching Quality (Z) also has an effect on Student Satisfaction (Z) Y) with a beta value of 0.475 and a significance level of 0.000 $<0.05$. Thus the variable $\mathrm{X} 1$ has an indirect effect on the variable $\mathrm{Y}$ and variable $\mathrm{X} 1$ also has an indirect effect on the variable $\mathrm{Y}$ through $\mathrm{Z}$ so it can be concluded that the variable $\mathrm{Z}$ functions as an intervening variable in relation to the effect of the variable $\mathrm{X} 1$ on the $\mathrm{Y}$ variable. The results of the car test show the value of $\mathrm{t} X 1$ count is 4.972269268 (tcount $>$ ttable) which is 1.965 . This means that the quality of learning perceived by students plays a role as a good moderating variable. Thus Hypothesis 6 is accepted. The results of this study support the results of the research of Xiao, Jian. (2015), researching at a university in China. One of the results of his research concluded that the Lecturer Commitment to Academic Achievement had a positive and significant effect on Student Satisfaction through Perceived Teaching Quality. Wilkins, S., Balakrishnan, M.S. and Huisman, J. (2012); Ahmed Al-Kuwaiti, Thennarasu Maruthamuthu (2014); Sookdeo, Suzette S., (2016), the results of her research concluded that students' perceptions of quality (including quality of learning) affect student satisfaction.

4. The Indirect Effect of Lecturer Competency (X2) on Student Satisfaction (Y) through Perceived Teaching Quality (Z)

The indirect effect of variable $\mathrm{X} 2$ on variable $\mathrm{Y}$ through variable $\mathrm{Z}$ can be calculated using the following formula:

$\mathrm{PTL}=($ pzx $x$ pyz $)$

Information :

$\mathrm{PTL}=$ Indirect Effect

pzx = Effect of Lecturer Competency (X2) on Teaching Quality $(Z)$ pyz $=$ Effect of Teaching Quality $(Z)$ on Student Satisfaction $(\mathrm{Y})$

So that:

$\mathrm{PTL}=0.261 \times 0.475=0.123$

Based on these calculations it can be explained that the indirect effect of Lecturer Competency (X2) on Student Satisfaction (Y) through Teaching Quality (Z) is $12.3 \%$. In addition, the result of the sub-structural calculation variable 
of Lecturer Competency (X2) has an effect on Teaching Quality $(Z)$ with a beta value of 0.261 and a significant level of $0.000<0.05$ then Teaching Quality $(Z)$ also has an effect on Student Satisfaction (Y) with a value of beta 0,475 and the level of significance is $0,000<0.05$. The Sobel test results showed the value of tcount X2 was 4.972269268 (tcount $>\mathrm{t}$ table), that is 1.965 . This means that the quality of learning perceived by students plays a role as a good moderating variable. Thus Hypothesis 7 is accepted. The results of this study are in line with the results of research Akareem H.S. \& Hossain, Sy.Sh. (2016) they examined university students in Bangladesh. The findings show students' perceptions about the quality of education, of course including the quality of learning in higher education have an impact on student satisfaction in college in Bangladesh. Butt, B.Z., \& Rehman, K. (2010) examined the factors that shape student satisfaction in tertiary institutions which ultimately are student loyalty to the institution. The results of his research concluded that the factors forming student satisfaction are the image of the institution, student expectations, the quality perceived by students, including the quality of learning perceived by students and other factors are the values perceived by students. Leyla Temizer, Ali Turkyilmazb (2012) conducted a study to measure student satisfaction from various aspects, such as university image, expectations, perceived quality, perceived value, and loyalty. The results of his study concluded that the factor was tested as a factor forming student satisfaction.
Douglas J., McClelland, R., \& Davies, J. (2008) conducted a study of 163 undergraduate students at Liverpool John Moores University in England. The results of the study concluded that students' perceptions of the quality of learning (one of them) affected student satisfaction and ended in student loyalty. Judin, T. (2018); Ganyaupfu, E.M. (2013); Ahmed Al-Kuwaiti, Thennarasu Maruthamuthu. 2014; Jiewanto, A, Laurens, C \& Nelloh, L (2012); Hakim, A. (2015); Leyla Temizer, Ali Turkyilmazb (2012); Tessema, TM, Ready, K \& Yu, W (2012); Wilkins, S., Balakrishnan, M.S. and Huisman, J. (2012); Suarman, Zahara Aziz2 \& Ruhizan Mohammad Yasin 2013, the results of the study concluded that the quality of learning (including learning methods and learning programs) affects student satisfaction.

\section{Total Influence}

The effect of the total variable $\mathrm{X}$ on $\mathrm{Y}$ through $\mathrm{Z}$ can be calculated using the following

Based on these calculations it can be explained that the effect of total Lecturer Commitment to Student Academic Achievement (X1) and Lecturer Competency (X2) on Student Satisfaction (Y) through Teaching Quality (Z) is $65.7 \%$.

Based on the explanation of the interpretation of the results of the path analysis test (which is already explained in detailed in previous sections), the summary of the direct and indirect relationships between variables is shown in the table below:

Table 12. Summary of Path Analysis Results

\begin{tabular}{|l|c|c|c|c|c|}
\hline $\begin{array}{c}\text { Variable } \\
\text { Relationship }\end{array}$ & $\begin{array}{c}\text { Direct } \\
\text { Effect }\end{array}$ & $\begin{array}{c}\text { Indirect } \\
\text { Effect }\end{array}$ & Total Effect & $\begin{array}{c}\text { Significant } \\
\text { Effect }\end{array}$ & Information \\
\hline $\mathrm{X} 1 \rightarrow \mathrm{Z}$ & 0,434 & - & - & 0,000 & H1 accepted \\
\hline $\mathrm{Z} \rightarrow \mathrm{Y}$ & 0,475 & - & - & 0,000 & H2 accepted \\
\hline $\mathrm{X} 1 \longrightarrow \mathrm{Y}$ & 0,119 & - & - & 0,000 & H3 accepted \\
\hline $\mathrm{X} 1 \rightarrow \mathrm{Z} \longrightarrow \mathrm{Y}$ & 0,$434 ; 0,475$ & 0,21 & 0,64 & 4,97 & H4 accepted \\
& & & & & \\
\hline
\end{tabular}

\begin{tabular}{|l|c|c|c|c|c|}
\hline $\mathrm{X} 2 \longrightarrow \mathrm{Z}$ & 0,261 & - & 0,261 & 0,000 & H5 accepted \\
\hline $\mathrm{Z} \longrightarrow \mathrm{Y}$ & 0,475 & - & 0,475 & 0,000 & H6 accepted \\
\hline $\mathrm{X} 2 \longrightarrow \mathrm{Y}$ & 0,119 & - & 0,119 & 0,000 & H7 accepted \\
\hline $\mathrm{X} 2 \longrightarrow \mathrm{Z} \longrightarrow \mathrm{Y}$ & 0,$261 ; 0,475$ & 0,123 & 0,657 & 4,97 & H8 accepted \\
& & & & & \\
\hline
\end{tabular}

\section{CONCLUSION}

This research raised several research questions. Firstly, how were the condition of lecturer's commitment to academic condition, lecturer competency, perceived teaching quality, and student satisfaction in Malang, Indonesia? Secondly, how did the direct effect of those variables on student satisfaction and indirect effect of those variables through variable of perceived teaching quality on student satisfaction?
The research result showed that the lecturer commitment to academic achievement is categorized as high; lecturer competency is categorized high. Students perceive learning quality (perceived teaching quality) is high (good) and Student satisfaction is categorized high or satisfied. Lecturer commitment to academic achievement has a direct or indirect significant positive effect on student satisfaction through perceived teaching quality. Lastly, lecturer competency has a direct or indirect significant positive effect on student satisfaction through perceived teaching quality. 


\section{SUGGESTION}

Based on research findings that the lecturer commitment to academic achievement and lecturer competency have a direct or indirect significant positive effect on student satisfaction through perceived teaching quality, then the rector/ staff (policy-maker) in colleges/ universities is expected to pay more attention to lecturer commitments, lecturer competencies, and quality of learning, by: 1) providing opportunities and support (material and non-

\section{REFERENCES}

1. Ahmad, J., Ather, M.R., \& Hussain, M. (2014). Impact of Big Five personality traits on job performance (Organizational commitment as a mediator). Management, Knowledge and Learning International Conference 2014.

2. Akareem, H. S., \& Hossain, S. S. (2016). Determinants of education quality: what makes students' perception different? Open review of educational research, 3(1), 52-67.

3. Akiri, A. A. (2013). Effects of Teachers' Effectiveness on Students' Academic Performance in Public Secondary Schools; Delta State - Nigeria. Journal of Educational and Social Research, 105;

4. Al-Mutairi, A. (2011). Factors Affecting Business Student' Performance in Arab Open University: The Case of Kuwait. International Journal of Business and Management. Vol. 6, No. 5, 146-155.

5. Alves, H., \& Raposo, M. (2009). The measurement of the construct satisfaction in higher education. Services Industries Journal, 29(2), 203-218.

6. Bonney, E. A., Amoah, D. P., Micah, S. A., Ahiamenyo, C., \&Lemaire, M. B. (2015). The Relationship Between the Quality of Teachers and Pupils Academic Performance in the STMA Junior High Schools of the Western Region of Ghana. Journal of Education and Practice. Vol. 6, No. 24, 139-150.

7. Butt, B. Z., \& Ur Rehman, K. (2010). A study examining the students satisfaction in higher education. Procedia-Social and Behavioral Sciences, 2(2), 54465450.

8. Clemes, M. D., Ozanne, L. K., \& Tram, L. (2001). An examination of students' perceptions of service quality in higher education. Journal of Marketing for Higher Education, 10(3), 1-20. material) for lecturers to attend workshops and training (particularly concerning strategy, approach, method, and models of learning), national and international seminars, English language learning, etc. in order to improve lecturer's commitment and competency, particularly the teaching quality of lecturer. 2) More supportive (nonmaterial) lecturers to enhance research activities at the faculty, university, national and even international level; 3) More support and facilitate (non-material for lecturers to carry out community service activities).

9. Choi Sang Long, Zaiton Ibrahim \& Tan Owee Kowang.International educationstudies vo 7 no 1. 2014. An analysis on the releationship between lecturer, competencies on student satisfaction.

10. Davison, E., \& Price, J. (2009). How do we rate? An evaluation of online student evaluations.

Assessment and Evaluation in Higher Education, 34(1), 51-65.

11. Djudin, T. (2018). The effect of teaching method and lecture program on students' satisfaction rates and academic achievement. Journal of Education, Teaching and Learning, 3(1), 121-128.

12. Douglas J., McClelland, R., \& Davies, J. (2008). The development of a conceptual model of student satisfaction with their experience in higher education. Quality Assurance in Education, 16(1), 19-35.

13. Douglas, J. A., Douglas, A., McClelland, R. J., \& Davies, J. (2015). Understanding student satisfaction and dissatisfaction: an interpretive study in the UK higher education context. Studies in Higher Education, 40(2), 329-349.

14. Duggal, M., \& Mehta, P. (2015). Antecedents to academic performance of college students: An empirical investigation. Paradigm, 19(2), 197-211.

15. Duraku, Z. H. (2014). Class Size, teaching quality and students' level of satisfaction with their academic performance. International Journal of Teaching and Education, 2(2), 39.

16. Elliott, K.M., \& Shin, D. (2010). Student satisfaction: An alternative approach to assessing this important concept. Journal of Higher Education Policy and Management, 24(2), 197-209.

17. Ganyaupfu, E.M. (2013). Factors Influencing Academic Achievement in Quantitative Courses among Business Students of Private Higher Education Institutions. Journal of Education and Practice. Vol. 4, No. 15, 57-65. 
18. Gee, N. C. (2015). The Impact of Lecturers' Competencies on Students' Satisfaction. Journal of Arts \& Social Sciences, 1(2), 74-86.

19. Hakim, A. (2015).Contribution of Competence Teacher (Pedagogical, Personality, Professional Competence and Social) On the Performance of Learning. The International Journal Of Engineering And Science. Vol. 4No.01-12.

20. Haque, HMJ, Das, D \& Farhana, R 2011, 'Satisfaction of student services in tertiary level: perspective Bangladesh', European Journal of Social Sciences, vol. 19, no. 2, pp. 286.

21. Jepsen, D. M., Varhegyi, M. M., \& Edwards, D. (2012). Academics' attitudes towards PhD students' teaching: Preparing research higher degree students for an academic career. Journal of Higher Education Policy and Management, 34(6), 629 6455.

22. Jiewanto, A., Laurens, C., \& Nelloh, L. (2012). Influence of service quality, university image, and student satisfaction toward WOM intention: A case study on Universitas Pelita Harapan Surabaya. Procedia-Social and Behavioral Sciences, 40, 16-23.

23. Kosgei, A., Mise, J. K., Odera, O., \& Ayugi, M. E. (2013). Influence of Teacher Characteristics on Students' Academic Achievement among Secondary Schools. Journal of Education and Practice.Vol. 4, No. 3, 76-82.

24. Kusumajati, D. A., Ruman, Y. S., \& Oktriono, K. (2017, June). The influence of lecturers' competencies towards students' performance motivation: a case study at higher education. In 2017 International Symposium on Educational Technology (ISET) (pp. 173-176). IEEE.

25. Langely, N., \& Jacobs, M. M. (2014). 5 Essential Skills for Successful School Leaders: Moving from Good to Great: Rowman \& Littlefield

26. Muzenda, A. (2013). Lecturers' Competences and Students' Academic Performance. International Journal of Humanities and Social Science Invention. Vol. 3, Issue. 1, 06ᄀ13.

27. Paechter, M., Maier, B., \& Macher, D. (2010). Students' expectations of, and experiences in elearning: Their relation to learning achievements and course satisfaction. Computers and Education, 54(1), 222-229.
28. Portoroz, Slovenia. Altbach, P.G. (2004). The past and future of Asian universities: Twenty-first century challenges. In P.G. Altbach \& T. Umakoshi (Eds.), Asian Universities: Historical perspectives and contemporay challenges (pp. 13-32). Baltimore: Johns Hopkins University Press.

29. Rehman, K. (2010). A study examining the students satisfaction in higher education. Procedia - Social and Behavioral Sciences, 2(2), 5446-5450.

30. Rienties, B., Heliot, Y.F., \& Jindal-Snape, D. (2013). Understanding social learning relations of international students in a large classroom using social network analysis. Higher Education, 66(4), 489-504.

31. Sojkin, B., Bartkowiak, P., \& Skuza, A. (2012). Determinants of higher education choices and student satisfaction: The case of Poland. Higher Education, 63(5), 565-581.

32. Tessema, M. T., Ready, K., \& Yu, W. (2012). Factors affecting college students' satisfaction with major curriculum: Evidence from nine years of data. International Journal of Humanities and Social Science, 2(2), 34-44.

33. Thien, L. M., \& Razak, N. A. (2014). Teacher commitment: a comparative study of Malaysian ethnic groups in three types of primary schools. Social Psychology of Education, 1-20.

34. Tsedzah, Victoria Adzoa, Obuobisa-Darko, . European Journal of Business and Management www.iiste.org ISSN 2222-1905 (Paper) ISSN 22222839 (Online) Vol.7, No.5, 2015. Theresa. Assessing Students' Satisfaction: An Approach to Help Improve Services Rendered to University Students.

35. Tyler, T.J., Hilton III, J., Plummer, K., \& Barret, D. (2014). Correlation between grade point averages and student evaluation of teaching scores: Taking a closer look. Assessment and Evaluation in Higher Education, 39(3), 339-348.

36. Undang-Undang R.I. Nomor 14 Tahun 2005 Tentang Guru dan Dosen. (2006). Jakarta: BPDharma Bhakti.

37. Wamala, R., \& Seruwagi, G. (2013). Teacher Competence and The Academic Achievement of Sixth Grade Students in Uganda. Journal of International Education Research. Vol. 9, No. 1, 83-90 
38. Wilkins, S., \& Huisman, J. (2012). UK business school rankings over the last 30 years (1980- 2010): trends and explanations. Higher Education, 63(3), 367382.

39. Xiao, J. \& Wilkins, S. (2015). The effects of lecturer commitment on student perceptions of teaching quality and student satisfaction in Chinese higher education. Journal of Higher Education Policy and Management, 37(1), 98-110. 